\title{
Reproductive seasonality and early life temperature sensitivity reflect vulnerability of a seaweed undergoing range reduction
}

\author{
Stefan Andrews ${ }^{1}$, Scott Bennett ${ }^{1}$, Thomas Wernberg ${ }^{1,2, *}$ \\ ${ }^{1}$ School of Plant Biology and UWA Oceans Institute, The University of Western Australia, 35 Stirling Highway, Crawley, \\ Western Australia 6009, Australia \\ ${ }^{2}$ Australian Institute of Marine Science, 39 Fairway, Crawley, Western Australia 6009, Australia
}

\begin{abstract}
Temperature is a major determinant of the performance and geographical ranges of marine species. Changes in temperature can therefore result in localised mortality and shifts in species distributions, but the phenology and temperature sensitivity of many important habitatforming seaweed species has not yet been investigated. Through field observations and culture growth experiments, the present study investigated the temperature sensitivity of reproductive timing, early post-settlement growth and survival, and recruitment success of the widespread foundation seaweed Scytothalia dorycarpa in Australia. In culture, the highest settlement densities and lowest mortality rates were achieved at $15^{\circ} \mathrm{C}$, and optimal temperatures for germling fertilisation occurred at $18^{\circ} \mathrm{C}$, whereas temperatures greater than $20^{\circ} \mathrm{C}$ delayed germling settlement and significantly increased mortality rates, with no germlings surviving at temperatures greater than $23^{\circ} \mathrm{C}$. Experimental findings were consistent with field observations that found adult reproductive development and gamete release to occur in synchronous pulses throughout the winter months, when seawater temperatures were $\sim 18^{\circ} \mathrm{C}$. Surveys of the latitudinal distribution of $S$. dorycarpa recruits showed significantly lower recruit densities in warmer, low-latitude reefs where summer maximum temperatures often exceed $23^{\circ} \mathrm{C}$ compared to much higher recruit densities in cooler pole-ward reefs where average summer maximum temperatures are 21 to $22^{\circ} \mathrm{C}$. The timing of reproduction, latitudinal distribution of recruits and culture temperature optima all indicate high temperature sensitivity among the early life stages of $S$. dorycarpa. These findings help to explain the rapid range contraction of this species following a 2011 marine heatwave off the southwest coast of Australia.
\end{abstract}

KEY WORDS: Thermal tolerance $\cdot$ Scytothalia Macroalgae - Reproduction - Recruitment · Germling $\cdot$ Distribution $\cdot$ Range contraction $\cdot$ Extreme event $\cdot$ Heat wave $\cdot$ Western Australia

\section{INTRODUCTION}

Temperature directly affects the survivorship, growth, reproduction and recruitment of most marine organisms, including seaweeds (Bolton \& Lüning 1982, Lüning et al. 1990, Kordas et al. 2011), and temperature is a strong driver of species distributions (Setchell 1915, Van Den Hoek 1982, Bree- man 1988, Tuya et al. 2012). Knowledge of the physiological responses of individual species to temperature, knowledge of their thermal limits to performance and identification of the life stages most susceptible to temperature variability is therefore necessary to understand the causes of geographical range expansion or contraction resulting from global warming and extreme climatic events 
(e.g. Walther et al. 2002, Root et al. 2003, Wernberg et al. 2011a). Understanding the physical thresholds leading to changes in species distributions holds particular significance for functionally important species whose addition or removal can result in cascading and often devastating effects on other species within the ecosystem (Ling 2008, Wernberg et al. 2013).

In the austral summer (January to April) of 2011, habitat-forming seaweeds along the south-western coast of Australia were severely affected by a marine heatwave, whereby soaring sea surface temperatures reached unprecedented levels $>3^{\circ} \mathrm{C}$ above long-term monthly averages for several consecutive weeks (Feng et al. 2013, Pearce \& Feng 2013, Wernberg et al. 2013). In the wake of this 'marine heatwave', many biological effects were reported, including extensions and contractions in species distributions, variations in recruitment and growthrates, impacts on trophic relationships and altered catch rates of exploited species (Pearce et al. 2011, Depczynski et al. 2012, Smale \& Wernberg 2012, Wernberg et al. 2013). Dominant seaweeds were particularly impacted, with large-scale decimations of important habitat formers. For example, the laminarian kelp Ecklonia radiata and the endemic fucoid Scytothalia dorycarpa, which jointly contribute $\sim 70 \%$ of the local seaweed canopy cover, significantly decreased due to the stressful conditions induced by the localised high temperatures (Wernberg et al. 2013). Strikingly, S. dorycarpa was completely eradicated from its northern range edge, resulting in a poleward contraction of up to $100 \mathrm{~km}$ (Smale \& Wernberg 2013).

Canopy-forming seaweeds play a key role in maintaining marine biodiversity by facilitating whole communities of organisms through habitat creation (Dayton 1972, Stachowicz 2001, Irving et al. 2004, Thomsen et al. 2010), and therefore, the loss of Scytothalia dorycarpa is likely to have widespread ecological consequences (Smale \& Wernberg 2013). However, very little is currently known about this habitat-forming fucoid, which is highly abundant throughout southern Australia. For example, online searches for articles in the ISI Web of Knowledge database currently return only 8 results for Scytothalia, which is substantially less than for the co-occurring canopy species Ecklonia and Sargassum which return 131 and 90 records, respectively (search performed 10 September 2013; for each genus, the search term included 'AND Australia'). The monospecific genus Scytothalia is endemic to southern Australia (Huismann 2000), having likely evolved from the cool temperate Tethyan marine flora on the south coast (Phillips 2001). The microscopic propagule stage and the early post-settlement stage of seaweeds are generally more susceptible to physical and biological stresses than adults (Brawley \& Johnson 1991, Lotze et al. 2001) and often represent a 'bottleneck' in the development and maintenance of seaweed populations (Steen \& Scrosati 2003). Nevertheless, recruitment is ultimately important for the maintenance of most seaweed populations and plays a substantial role in stabilising densities of adults (e.g. Deysher \& Norton 1981, Kendrick \& Walker 1994). Whilst strong correlative evidence between declining $S$. dorycarpa abundance and increasing water temperatures along latitudinal gradients has led to suggestions of its value as an indicator species for climate impacts (Smale et al. 2010, Wernberg et al. 2011b, Smale \& Wernberg 2013), very little is known about the seasonal timing of development and thermal tolerance throughout its life history. Developing our understanding of such processes is critical in order to understand the capacity of such species to cope with both gradually increasing ocean temperatures and extreme events, such as the 2011 marine heatwave.

The aim of the present study, therefore, was to determine the seasonal timing of gamete development and release of Scytothalia dorycarpa and to identify the optimal and lethal temperatures for its settlement, early post-settlement growth and survival. We then aimed to examine whether these temperatures were reflected in its geographical patterns of recruitment within cooler and warmer locations along its west coast distribution. Given the species' observed vulnerability to the 2011 marine heat wave, we predicted that optimal settlement and growth temperatures would reflect water temperatures found at the cooler end of the species range $\left(<20^{\circ} \mathrm{C}\right)$, whereas lethal limits would occur in waters similar to summer maxima in northern populations $\left(23^{\circ} \mathrm{C}\right)$. Furthermore, we predicted that recruitment rates of $S$. dorycarpa would be highest at the cooler locations and lowest toward the warm water limit of its geographical distribution.

\section{MATERIALS AND METHODS}

\section{Study region}

The temperate west coast of Australia is characterised by a relatively shallow (5 to $15 \mathrm{~m}$ ) subtidal 
limestone platform, which extends 5 to $10 \mathrm{~km}$ out from the intertidal zone and runs virtually uninterrupted along the coast between Geraldton $\left(\sim 28^{\circ} \mathrm{S}\right)$ and Cape Leeuwin $\left(\sim 34^{\circ} \mathrm{S}\right)$, beyond which sandstone and granite intrusions dominate the reef geomorphology. Scytothalia dorycarpa is abundant along the coast poleward of $\sim 31^{\circ} \mathrm{S}$, the current range edge of the species (Smale \& Wernberg 2013). The sea water temperature for this coast is highly influenced by the warm, poleward-flowing Leeuwin current and ranges between mean summer maxima of 22 to $24^{\circ} \mathrm{C}$ and winter minima of approximately 17 to $19^{\circ} \mathrm{C}$ for Hamelin Bay and Jurien Bay respectively (Fig. 1). Due to the directional flow of the current, upwelling is suppressed (Pearce 1991), resulting in consistently low nutrient concentrations (Lourey et al. 2006, Wernberg et al. 2010) and a gradual temperature gradient of 1 to $3^{\circ} \mathrm{C}$ (Smale \& Wernberg 2009). Seaweed grazing pressure from herbivorous fishes and invertebrates is also relatively low and consistent among locations (Vanderklift et al. 2009), creating relatively consistent biotic and environmental conditions throughout the region with the exception of temperature (Smale \& Wernberg 2009, Wernberg et al. 2010).

\section{Field observations of receptacle development}

From January to September 2012, 20 collections of Scytothalia dorycarpa specimens were made from 3 subtidal reefs (at least $1 \mathrm{~km}$ apart) within Marmion Marine Park, Perth, Western Australia (31 47.5' S, $115^{\circ} 42.0^{\prime} \mathrm{E}$; Fig. 1). At each collection, 12 large individual seaweeds were sampled from each reef. Receptacles (reproductive structures) were examined under a dissecting microscope, and the reproductive maturity of Scytothalia was recorded by assessing the frequency of individuals with receptacles containing (1) mature gametes, (2) developing gametes or (3) empty gametangia (section of reproductive structure in which the gametes are produced). In the fucoid life cycle, a diploid adult produces haploid eggs and spermatozoids, which, following fertilisation, develop directly into diploid juveniles and grow into adult thalli. In the present paper, we refer to haploid stages as 'gametes' and post-settlement fertilised stages as 'germlings'. Receptacles were classified as holding 'mature gametes' based on the presence of either already extruded gametes in an external mucilage layer surrounding the receptacle and/or gametes being extruded
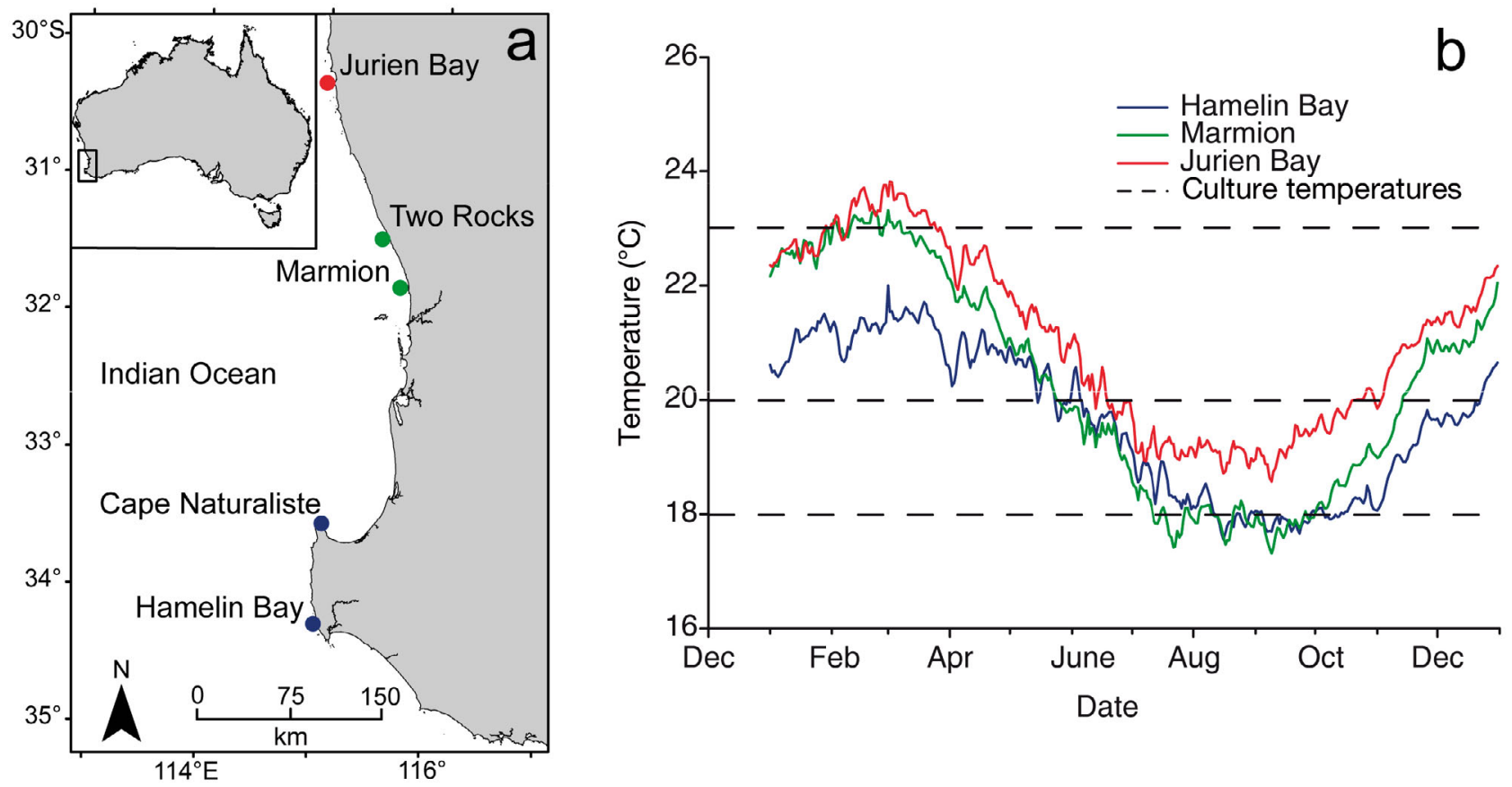

Fig. 1. (a) South-western Australia: blue spots illustrate the 'cool' study locations, green spots illustrate the 'warm' study locations, and the red spot marks the former range edge of Scytothalia dorycarpa up until 2011 (Smale \& Wernberg 2013). (b) Daily mean seawater temperature averaged from 2006 to 2010. The black dashed lines illustrate 3 of the 4 temperatures from the germling culture experiment. Temperature data comes from values averaged across 3 long-term Tidbit temperature loggers recording at $\sim 10 \mathrm{~m}$ depth within each of the respective locations. The Hamelin Bay and Marmion loggers were situated within 
through the conceptacle (pits within the reproductive structures where the gametes are formed). Receptacles were classified as holding 'developing gametes' if there were visible signs of gametogenesis, such as swollen receptacles with darkened conceptacle pits (e.g. Fig. 2 insert), and if, upon dissection, the gametangia were visibly holding immature gametes.

\section{Culture of early post settlement stages}

Germling growth was recorded over 4 temperature treatments: $15^{\circ} \mathrm{C}, 18^{\circ} \mathrm{C}, 20^{\circ} \mathrm{C}$ and $23^{\circ} \mathrm{C}$ with 3 replicate $10 \mathrm{l}$ aquaria $(280 \times 200 \times 150 \mathrm{~mm})$ within each treatment. Temperatures were chosen to reflect the annual temperature range of reefs along Scytothalia dorycarpa's west coast distribution. Each tank contained unfiltered seawater and was lined with 12 sand-blasted acrylic settlement plates $(30 \times 100 \mathrm{~mm})$. Accurate, stable temperatures $\left( \pm 0.2^{\circ} \mathrm{C}\right)$ were provided using $50 \mathrm{~W}$ adjustable Jager aquarium heaters, individually calibrated using HOBO temperature loggers. The coolest treatment temperature tanks $\left(15^{\circ} \mathrm{C}\right)$ were immersed in a 'cool bath' held at $13^{\circ} \mathrm{C}$ by a TECO TR10 chillier unit. Each treatment received natural light with an average daily maximum between 10 and $20 \mu \mathrm{mol} \mathrm{m} \mathrm{m}^{-2} \mathrm{~s}^{-1}$ and natural photoperiod ( 11.5 to 12 daylight hours). Individual aquaria were vigorously aerated throughout the duration of the experiment using $200 \mathrm{~mm}$ aquarium air stones. A total of $25 \%$ of the seawater in the experimental aquaria was changed every $3 \mathrm{~d}$, the salinity was monitored daily with a hand-held refractometer, and levels were kept constant by adding small amounts of deionised water as required.

Collection and treatment methods of Scytothalia dorycarpa for the growth experiment were developed from previous studies on similar fucoids (e.g. Pollock 1970, McLachlan et al. 1971, Norton 1977, Niemeck 1978). Four adult $S$. dorycarpa with fertile receptacles were collected from 3 subtidal reefs ( $\mathrm{n}=$ 12) within Marmion Marine Park, Western Australia (described above), on 9 September 2012 and transported to the laboratory in darkness using moist calico bags. The seaweeds were brushed to eliminate surface epiphytes, vigorously washed with deionised water for several minutes and laid out to dry on paper tissue at room temperature at an irradiance of $\sim 30 \mu \mathrm{mol}$ photons $\mathrm{m}^{-2} \mathrm{~s}^{-1}$. After $1 \mathrm{~h}, 12$ thallus sections ( $10 \mathrm{~cm}$ in length) containing high densities of receptacles were excised from each seaweed, mixed together and evenly distributed among the replicate aquarium tanks. Seaweed sections were left in the aquaria for $24 \mathrm{~h}$ to induce the release of gametes, after which time they were discarded to avoid interferance with settlement.

After 12 h, 36 h, 3 d, 1 wk and 2 wk of treatment, 2 randomly selected settlement plates were destructively sampled from each replicate tank. The total number of settled germlings, fertilisation status and mortality were observed for each slide using a light microscope. Fertilisation was categorised as any early sign of cell division or asymmetry of the germling, and germlings that had structurally collapsed were considered dead.

\section{Latitudinal distribution of recruits}

Recruit densities were sampled along a $\sim 400 \mathrm{~km}$ stretch of north-south running coastline in the southwest of Australia, covering the latitudes $34^{\circ} \mathrm{S}$ to $31^{\circ} \mathrm{S}$ (Fig. 1). Northern locations were Two Rocks $\left(31^{\circ} 29.0^{\prime} \mathrm{S}, \quad 115^{\circ} 32.1^{\prime} \mathrm{E}\right)$ and Marmion $\left(31^{\circ} 47.3^{\prime} \mathrm{S}, 115^{\circ} 01.1^{\prime} \mathrm{E}\right)$. Southern locations were Cape Naturaliste $\left(33^{\circ} 32.0^{\prime} \mathrm{S}, 115^{\circ} 02.0^{\prime} \mathrm{E}\right)$ and Hamelin Bay $\left(34^{\circ} 15.2^{\prime} \mathrm{S}, 115^{\circ} 01.1^{\prime} \mathrm{E}\right)$. At each location, 3 reefs were sampled (at least $1 \mathrm{~km}$ apart). Sites were selected based on the presence of mixed seaweed canopies, consisting of Scytothalia dorycarpa, Sargassum spp. and Ecklonia radiata. 'Sargassum' in the present paper is used to denote a complex of several species, primarily from the Arthrophycus subgenus, which cannot be differentiated as recruits. At each reef, the density of adults and recruits were recorded within 20 randomly placed $0.5 \times 0.5 \mathrm{~m}$ quadrats (each at least $10 \mathrm{~m}$ apart). Recruits were classified into 3 size classes $(0-5 \mathrm{~cm}, 5-10 \mathrm{~cm}$ and $10-20 \mathrm{~cm})$ and did not have receptacles. All reefs were sampled in austral autumn (28 April 2012 to 2 May 2012) and resampled in winter (2 July 2012 to 8 July 2012).

\section{Statistical analysis}

One-way analysis of variance (ANOVA) using $\mathrm{R}$ statistical software (R Development Core Team 2012) was used to test the null hypothesis that no differences in settlement densities (living and non-living), survivorship (total surviving settled germling densities) and percentage of survivorship among temperature treatments (fixed factor) would be found throughout the culturing experiment after (1) $3 \mathrm{~d}$, (2) $1 \mathrm{wk}$ and (3) $2 \mathrm{wk}$. Data were checked for normality and homogeneity of variance through visual inspection of scatter plots and the distribution of residuals. 
Percentage of survivorship was transformed for the analyses using a square root-arcsine transformation to account for the bound structure of the data. Tukey's HSD post-hoc analyses were performed on significant results, to determine the among-treatment differences in surviving germling density and fertilisation rates.

Permutational analysis of variance (PERMANOVA; Anderson 2001) using Primer 6 software was used to test (1) the null hypothesis that no differences in recruit densities would be detected among seasons (fixed, orthogonal factor) and locations (fixed factor) for each of the 3 seaweed species (Scytothalia dorycarpa, Ecklonia radiata and Sargassum spp.) and (2) the null hypothesis that no differences in recruit densities would exist among seasons and locations for $3 S$. dorycarpa recruit size categories $(0-5,5-10$ and 10-20 cm). These analyses were based on Euclidian distances and 999 permutations of the residuals under a reduced model. An a priori planned contrast (Two Rocks and Marmion vs. Dunsborough and Hamelin Bay) tested for differences between southern and northern latitudinal regions.

\section{RESULTS}

\section{Field observations of receptacle development}

Monthly observations of the development of Scytothalia dorycarpa receptacles indicated that gametes started to develop in late March (Fig. 2). Samples collected on 24 March showed the first sign of swollen receptacles with darkened surfaces (e.g. Fig. 2a inset). In any one individual, the development of receptacles was at a similar state of maturity. However, there was considerable variation among individuals. The percentage of $S$. dorycarpa sampled with developing gametes steadily increased from March to May. Developing gametes were not considered mature until they were found to excrete gametes, which first occurred 6 wk after the first signs of development on 5 May. Throughout May to August, $>70 \%$ of $S$. dorycarpa were consistently found to release mature gametes, whilst still developing immature gametes. Throughout July and August, specimens had developing and mature gametes on almost all occasions. September was the first month in the reproductive season that the percentage of receptacles with mature gametes (75\%) exceeded those still developing gametes. Receptacles on $42 \%$ of $S$. dorycarpa had empty gametangia, potentially indicating the final pulse of release for the season.
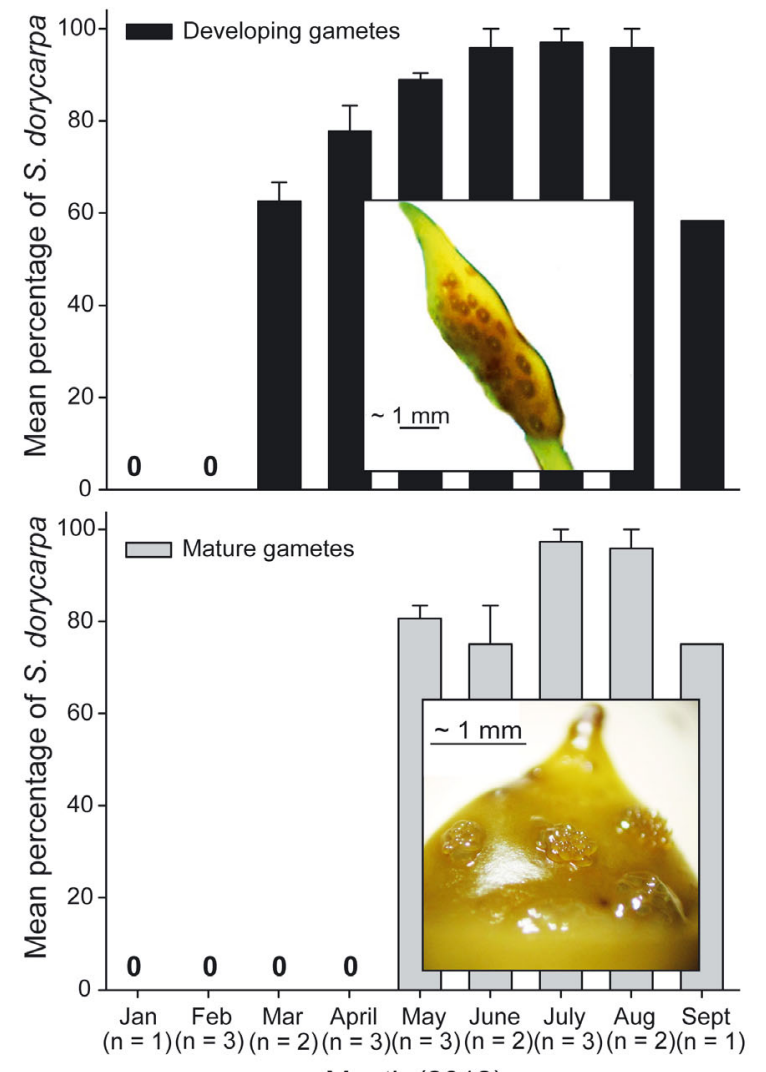

Month (2012)

Fig. 2. Seasonality of receptacle development of Scytothalia dorycarpa. Mean percentage of $S$. dorycarpa sampled (a) with developing gametes (inset: swollen receptacles with darkened patches = conceptacles) and (b) with mature gametes (inset: mature gametes being extruded through receptacle osteole). Mean values $\pm 1 \mathrm{SE}$ ( $\mathrm{n}=$ number of collection days)

The expulsion of gametes in Scytothalia dorycarpa was a repeated synchronous occurrence, with all mature individuals in the same stand extruding their gametes simultaneously (spawning). Following an extended stormy period in May/June, in situ observations recorded that the receptacles of $94 \%$ of S. dorycarpa were bearing gametes externally in an outer mucilage layer (e.g. Fig. 3). In calm conditions following the storm, the receptacles had 'shed' their gametes within $5 \mathrm{~d}$. There were no evident patterns of expulsion associated with lunar or tidal cycles, and the exact timing of expulsion varied among locations.

\section{Culture of early post-settlement stages}

Settlement densities increased over time in the 15, 18 and $20^{\circ} \mathrm{C}$ treatments; however, very few germlings were observed at $23^{\circ} \mathrm{C}$, and of those few, zero survived (Fig. 4). Significant differences among tem- 


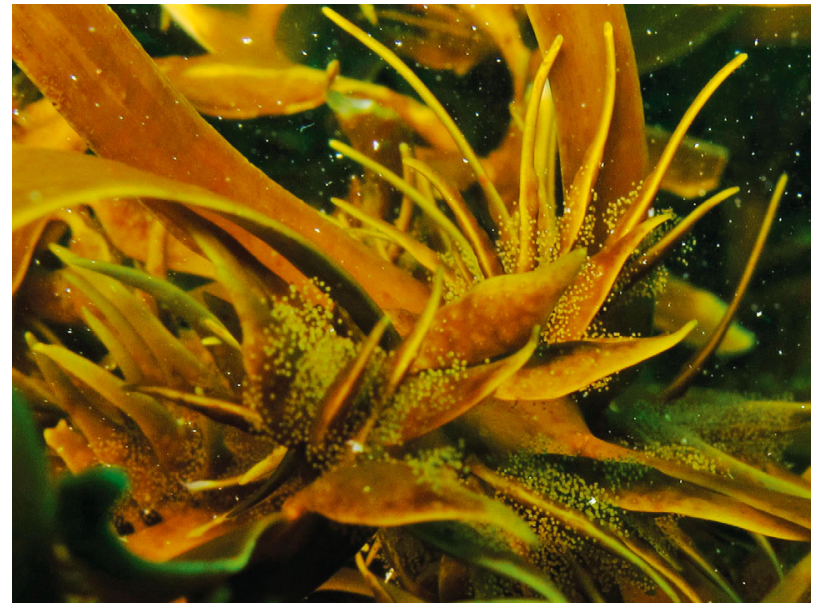

Fig. 3. Scytothalia dorycarpa receptacles holding gametes externally in mucilage, June 2012

perature treatments were observed after $3 \mathrm{~d}, 1 \mathrm{wk}$ and 2 wk (Table $1 \mathrm{a})$, and the $15^{\circ} \mathrm{C}$ treatment had higher densities of alive germlings than both the 20 and $23^{\circ} \mathrm{C}$ treatments at every time interval (Fig. 4). The $18^{\circ} \mathrm{C}$ treatment had significantly higher living germling densities than $23^{\circ} \mathrm{C}$ at every time period but did not statistically differ from the $20^{\circ} \mathrm{C}$ treatments, despite averaging slightly higher densities. Despite a substantial rise in settlement densities after 2 wk across 3 of the culture temperatures, survivorship significantly decreased with increasing temper- ature, and at $20^{\circ} \mathrm{C}, 90 \%$ of these germlings were dead after $2 \mathrm{wk}$, whilst no surviving germlings were found at $23^{\circ} \mathrm{C}$ (Table 1c).

Temperature also significantly affected fertilisation rates, with the percentage of fertilised germlings significantly higher in $15^{\circ} \mathrm{C}$ and $18^{\circ} \mathrm{C}$ treatments throughout the duration of the experiment (Fig. 5). The $15^{\circ} \mathrm{C}$ and $18^{\circ} \mathrm{C}$ treatments consistently displayed significantly higher fertilisation rates than the $20^{\circ} \mathrm{C}$ treatment and in particular the $23^{\circ} \mathrm{C}$ treatment, where no fertilised individuals were observed throughout the experiment. Germling growth rates varied markedly within treatments, and their size (excluding rhizoid) ranged from 300 to $700 \mu \mathrm{m}$ after $2 \mathrm{wk}$. Germination of germlings (e.g. Fig. 6b) was faster at $18^{\circ} \mathrm{C}$, with over $50 \%$ having fertilised within $12 \mathrm{~h}$ (Fig. 5) compared to no fertilisation of germlings cultured at $15^{\circ} \mathrm{C}$ over the same time. After $3 \mathrm{~d}, 100 \%$ of the surviving germlings cultured at $15^{\circ} \mathrm{C}$ and $18^{\circ} \mathrm{C}$ and $20^{\circ} \mathrm{C}$ had fertilised.

\section{Latitudinal study of recruit densities}

Recruit densities for Scytothalia dorycarpa were significantly higher in southern locations (16.2 \pm 16.5 recruits $\mathrm{m}^{-2}$ ) compared to northern locations $\left(1.5 \pm 2.6\right.$ recruits $\mathrm{m}^{-2}$; Table 2, Fig. 7$)$. For each size category, recruit densities in southern locations were significantly higher than recruit densities in northern locations and were consistently higher in southern locations over both autumn

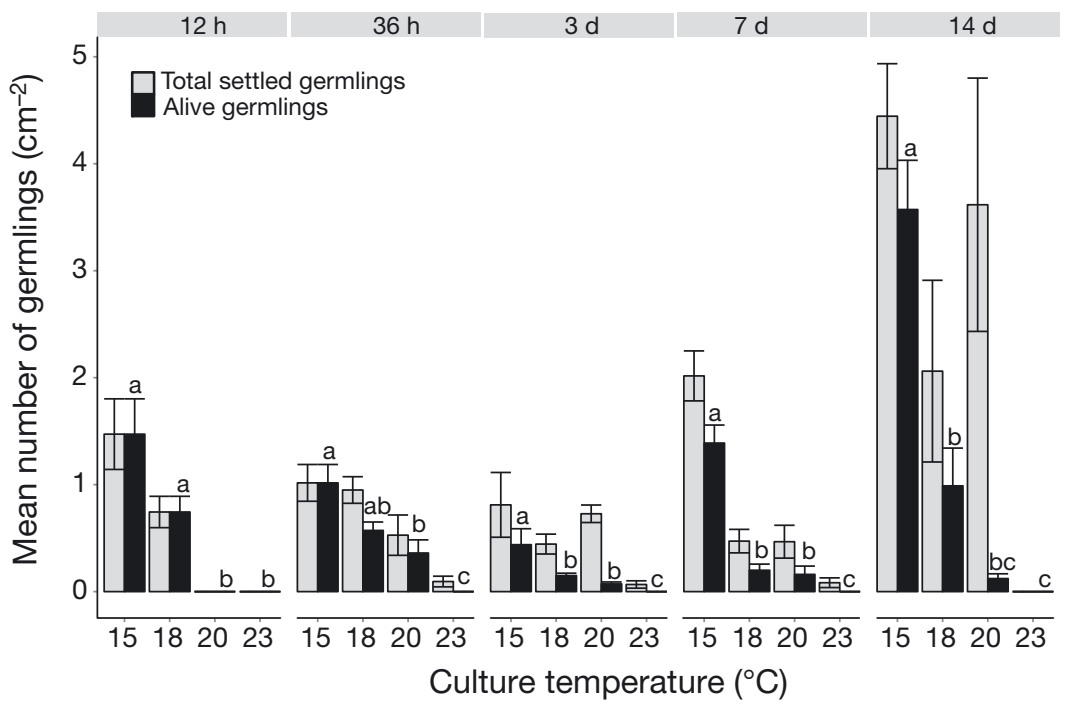

Fig. 4. Scytothalia dorycarpa. Mean $( \pm 1 \mathrm{SE})$ settlement densities $\left(\mathrm{cm}^{-2}\right)$ of germlings cultured at $15,18,20$ and $23^{\circ} \mathrm{C}(\mathrm{n}=4)$. Bars indicate mean densities of (grey bars) total settled germlings (dead and alive) and (black bars) living settled germlings. Letters indicate significant differences in the number of 'Alive germlings' among the 4 temperature treatments, based on Tukey HSD post-hoc results. Separate ANOVAS were performed for each time period and winter. There were consistently more $S$. dorycarpa recruits at Cape Naturaliste than at all the other locations in autumn and winter. Small $S$. dorycarpa recruit densities were $\sim 4$ fold higher at Cape Naturaliste than all other locations, and there was a significant difference in the densities of this size category for locations interacting with the season (Fig. 7, Table 2c).

Ecklonia radiata recruit densities were significantly different amongst locations (Table 3), and although there was no significant difference between regions, densities were generally higher in southern locations (3.5 \pm 4.6 recruits $\mathrm{m}^{-2}$ ) than northern locations $\left(2.4 \pm 2.6\right.$ recruits $\left.\mathrm{m}^{-2}\right)$. There were significant interactions between season $x$ location and season $\times$ region for Sargassum recruit densities (Table 3). Sargassum recruits were the most abun- 
Table 1. Single-factor analysis of variance (ANOVA) testing for differences in Scytothalia dorycarpa germling (a) settlement density (total number of settled germlings, dead and alive), (b) survivorship (total number of alive germlings) and (c) survivorship percentage (square-root arcsine transformed) between different temperature treatments ranging from 15 to $23^{\circ} \mathrm{C}$ at $3 \mathrm{~d}, 1 \mathrm{wk}$ and $2 \mathrm{wk}$ of culture. Values in bold are significant with $\mathrm{p}<0.05$

\begin{tabular}{|c|c|c|c|c|c|c|c|c|c|c|}
\hline \multirow{2}{*}{ Source } & \multirow[t]{2}{*}{$\mathrm{df}$} & \multicolumn{3}{|c|}{$-3 d-$} & \multicolumn{3}{|c|}{$1 \mathrm{wk}-$} & \multicolumn{3}{|c|}{$-2 \mathrm{wk}-$} \\
\hline & & MS & $F$ & $\mathrm{p}$ & MS & F & $\mathrm{p}$ & MS & $F$ & $\mathrm{p}$ \\
\hline \multicolumn{11}{|c|}{ (a) Settlement density } \\
\hline Temperature & 3 & 610.00 & 4.17 & 0.02 & 3970.70 & 31.90 & $<0.01$ & 20640.10 & 6.47 & $<0.01$ \\
\hline Error & 20 & & 146.10 & & & 124.49 & & & 3191.6 & \\
\hline \multicolumn{11}{|c|}{ (b) Survivorship } \\
\hline Temperature & 3 & 199.90 & 6.44 & $<0.01$ & 2212.80 & 43.55 & $<0.01$ & 6638.50 & 43.55 & $<0.01$ \\
\hline Error & 20 & & 31.10 & & & 50.81 & & & 50.81 & \\
\hline \multicolumn{11}{|c|}{ (c) Survivorship percentage } \\
\hline Temperature & 3 & 1.51 & 15.65 & $<0.01$ & 0.99 & 17.86 & $<0.01$ & 1.48 & 32.40 & $<0.01$ \\
\hline Error & 20 & & 0.07 & & & 0.06 & & & 0.05 & \\
\hline
\end{tabular}

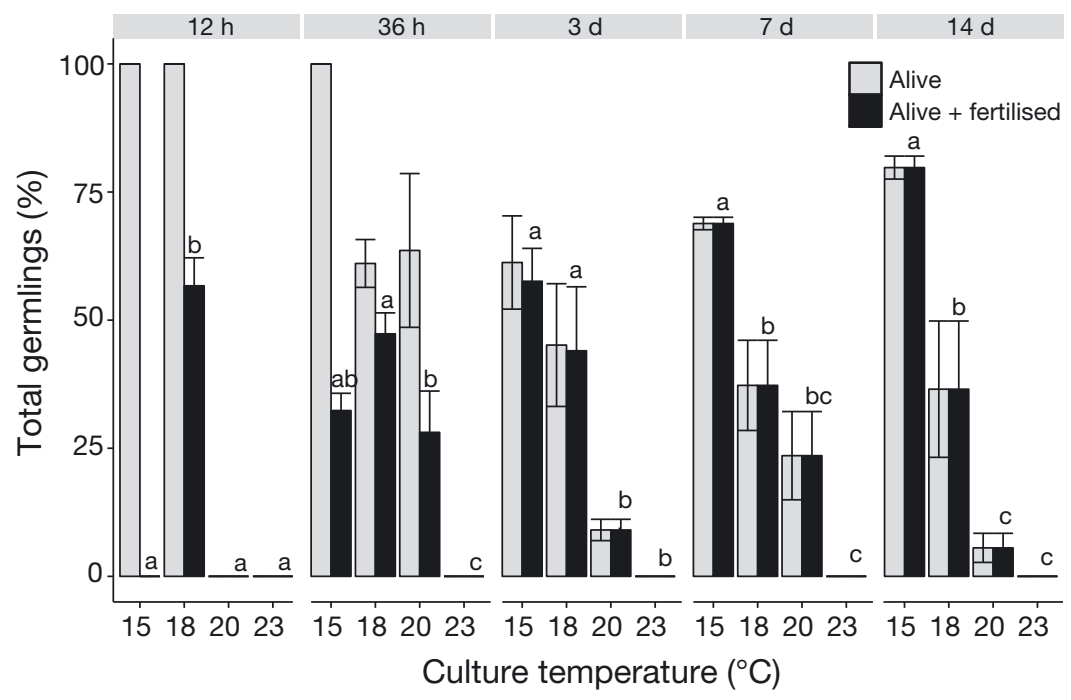

Fig. 5. Scytothalia dorycarpa. Mean ( $\pm 1 \mathrm{SE})$ percentage of living settled germlings cultured at $15,18,20$ and $23^{\circ} \mathrm{C}(\mathrm{n}=4)$. Grey bars indicate mean percentage of living germlings, and black bars indicate the mean density of fertilised germlings. Letters indicate significant differences in the percentage of fertilised germlings among the 4 temperature treatments, based on Tukey HSD post-hoc results. Separate ANOVAS were performed for each time period dant of all species, with densities averaging $22.1 \pm 21.5$ recruits $\mathrm{m}^{-2}$ in southern locations, which was similar to the densities in northern locations (19.3 \pm 20.9 recruits $\mathrm{m}^{-2}$ ).

\section{DISCUSSION}

The results from the present study highlight the thermal sensitivity of the pre- and early post-settlement stages of Scytothalia dorycarpa. In culture, temperatures $>20^{\circ} \mathrm{C}$ delayed germling settlement and significantly increased mortality. These findings were strongly supported by a sharp drop-off in the number of $S$. dorycarpa recruits on reefs from cool to warmer climates, and reproduction was constrained to winter months, coinciding with sub$20^{\circ} \mathrm{C}$ water temperatures.

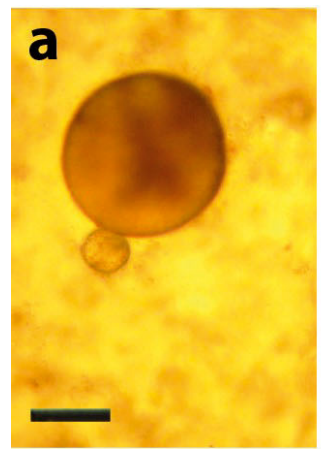

$12 \mathrm{~h}$

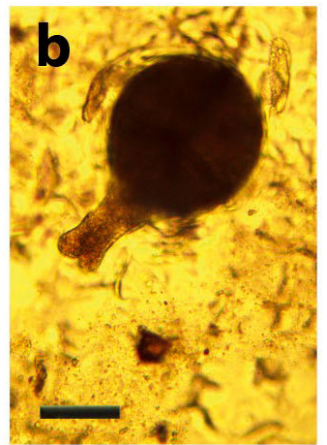

$36 \mathrm{~h}$

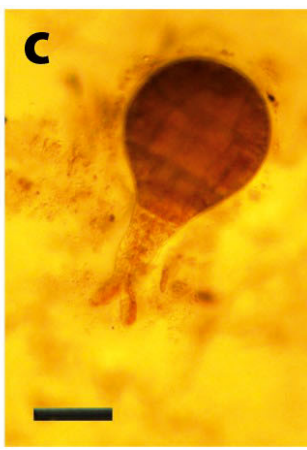

$3 d$

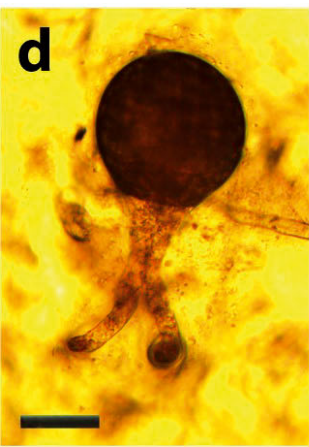

$7 d$

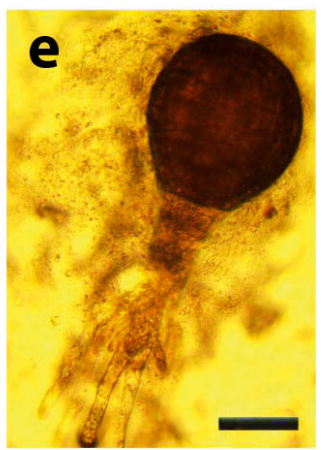

$14 \mathrm{~d}$

Fig. 6. Scytothalia dorycarpa. Images of germling development at $15^{\circ} \mathrm{C}$ across the 5 observed time intervals (cf. Fig. 5). Scale bar $=200 \mu \mathrm{m}$ 
Table 2. Three-factor permutational analysis of variance (PERMANOVA) for Scytothalia dorycarpa recruit densities in size categories large (10 to $20 \mathrm{~cm}$ ), intermediate $(5$ to $10 \mathrm{~cm}$ ) and small $(0$ to $5 \mathrm{~cm}$ ) with season (autumn vs. winter), location, region (a priori planned contrast; north representing northern locations Two Rocks and Marmion and south representing southern locations Cape Naturaliste and Hamelin Bay), Season $\times$ Location interaction and Season $\times$ Region interaction. Values in bold are significant with $\mathrm{p}<0.05$

\begin{tabular}{|c|c|c|c|c|c|c|c|c|c|c|}
\hline \multirow[t]{2}{*}{ Source } & \multirow[t]{2}{*}{ df } & \multicolumn{3}{|c|}{$-10-20 \mathrm{~cm}$} & \multicolumn{3}{|c|}{$-5-10 \mathrm{~cm}$} & \multirow[b]{2}{*}{ MS } & \multirow{2}{*}{$\begin{array}{c}0-5 \mathrm{~cm} \\
F\end{array}$} & \multirow{2}{*}{$\mathrm{p}$} \\
\hline & & MS & $F$ & $\mathrm{p}$ & MS & $F$ & $\mathrm{p}$ & & & \\
\hline Season & 1 & 0.62 & 2.23 & 0.17 & 0.08 & 0.60 & 0.47 & 0.51 & 6.56 & 0.19 \\
\hline Location & 3 & 7.35 & 8.85 & $<0.01$ & 1.08 & 7.93 & $<0.01$ & 2.07 & 26.64 & $<0.01$ \\
\hline Region (North vs. South) & 1 & 7.32 & 31.50 & $<0.01$ & 2.67 & 17.54 & $<0.01$ & 3.92 & 14.87 & $<0.01$ \\
\hline Season $\times$ Location & 3 & 0.39 & 1.40 & 0.26 & 0.10 & 0.76 & 0.54 & 0.66 & 8.44 & $<0.01$ \\
\hline Season × Region & 1 & 0.98 & 2.21 & 0.06 & 0.01 & 0.04 & 0.84 & 0.24 & 0.91 & 0.39 \\
\hline Error & 23 & 0.28 & & & 0.14 & & & 0.07 & & \\
\hline
\end{tabular}

Table 3. Three-factor permutational analysis of variance (PERMANOVA) for Scytothalia dorycarpa, Ecklonia radiata and Sargassum spp. recruit densities with season (autumn vs. winter), region (a priori planned contrast; north representing northern locations Two Rocks and Marmion, south representing southern locations Cape Naturaliste and Hamelin Bay), Season $\times$ Location interaction and Season $\times$ Region interaction. Values in bold are significant with $p<0.05$

\begin{tabular}{|c|c|c|c|c|c|c|c|c|c|c|}
\hline \multirow[t]{2}{*}{ Source } & \multirow[t]{2}{*}{ df } & \multicolumn{3}{|c|}{ S. dorycarpa } & \multicolumn{3}{|c|}{ E. radiata } & \multicolumn{3}{|c|}{ Sargassum } \\
\hline & & MS & $F$ & $\mathrm{p}$ & MS & $F$ & $\mathrm{p}$ & MS & $F$ & $\mathrm{p}$ \\
\hline Season & 1 & 0.49 & 0.06 & 0.89 & 0.55 & 3.39 & 0.08 & 14.57 & 1.23 & 0.30 \\
\hline Location & 3 & 25.53 & 3.26 & 0.02 & 0.65 & 3.96 & 0.02 & 9.51 & 0.81 & 0.49 \\
\hline Region (North vs. South) & 1 & 60.33 & 8.46 & $<0.01$ & 0.44 & 1.99 & 0.17 & 3.08 & 0.21 & 0.65 \\
\hline Season $\times$ Location & 3 & 1.10 & 0.14 & 0.98 & 0.12 & 0.76 & 0.55 & 59.46 & 5.04 & 0.01 \\
\hline Season $\times$ Region & 1 & 2.38 & 20.33 & 0.69 & 0.08 & 0.39 & 0.54 & 94.80 & 0.02 & 0.03 \\
\hline Error & 23 & 7.84 & & & 0.16 & & & 11.81 & & \\
\hline
\end{tabular}

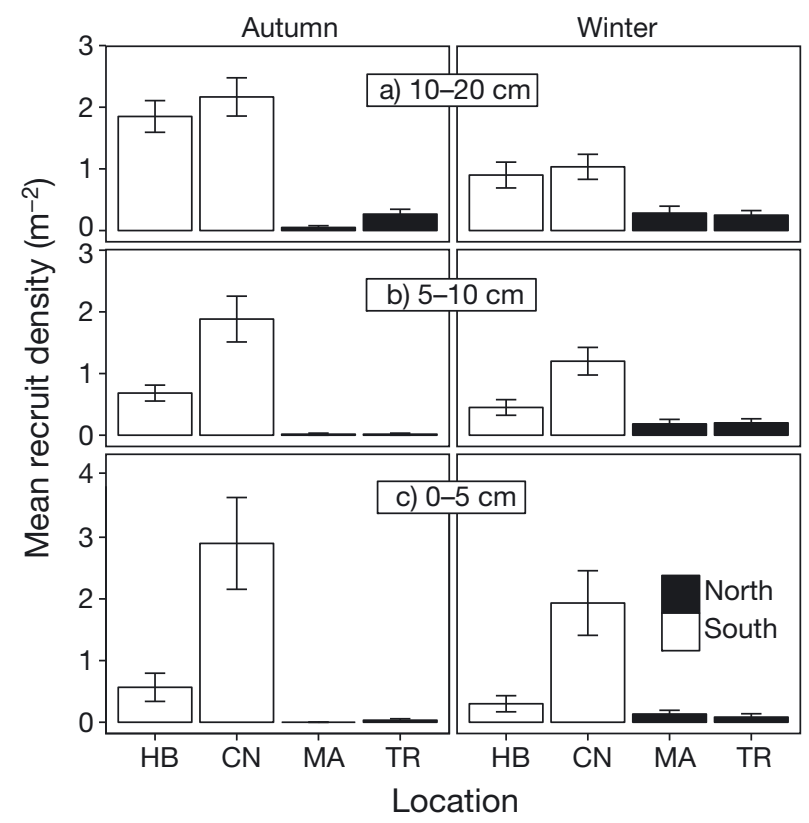

Fig. 7. Scytothalia dorycarpa. Mean $( \pm 1 \mathrm{SE})$ number of recruits $\mathrm{m}^{-2}$, sampled in autumn and winter $2012(\mathrm{n}=3$ reefs), reported in each size bin $(10-20 \mathrm{~cm}, 5-10 \mathrm{~cm}$ and $0-5 \mathrm{~cm})$. White bars: locations in the southern region (HB: Hamelin Bay; CN: Cape Naturaliste); black bars: locations in the northern region (MA: Marmion; TR: Two Rocks)

\section{Thermal sensitivity of early post-settlement stages}

The early life history stages of Scytothalia dorycarpa were sensitive to high temperatures, particularly those above $20^{\circ} \mathrm{C}$. In culture experiments, temperature significantly affected germling survivorship, which was highest at the coolest treatment temperature $\left(15^{\circ} \mathrm{C}\right)$. Mortality rates at the 2 highest treatment temperatures $\left(20^{\circ} \mathrm{C}\right.$ and $\left.23^{\circ} \mathrm{C}\right)$ were $90 \%$ and $100 \%$ respectively. Low rates of surviviorship and the observed structural collapse of germlings at high temperatures may be associated with thermally sensitive processes, such as the denaturation of proteins, and damage to heat-labile enzymes or membranes (Lüning et al. 1990).

In the most extensive review of the temperature tolerance of seaweeds, Lüning (1984) found upper temperature limits for germling survival in brown seaweeds to range from $18^{\circ} \mathrm{C}$ (Chorda tomentosa) to $28^{\circ} \mathrm{C}$ (Fucus vesiculosus and F. spiralis). More recently, Chu et al. (2012) reported that germlings of the intertidal fucoid Sargassum thunbergii exhibited rapid growth and low mortality when exposed to warming conditions and were able to tolerate culture 
temperatures of $35^{\circ} \mathrm{C}$, several degrees higher than adult $S$. thunbergii lethal limits (Hiroko et al. 2005). Ultimately, however, if the lethal limits of a particular ontogenetic stage or population overlap with the ambient ocean temperatures for prolonged periods, it will impact the demographic structure of the population or cause a range contraction of the species to cooler conditions (e.g. Edwards \& HernándezCarmona 2005, Wernberg et al. 2011a). For Scytothalia dorycarpa, the persistence of adult populations in locations where summer temperatures exceed $23^{\circ} \mathrm{C}$ suggests that the species undergoes an ontogenetic shift to slightly higher thermal tolerance, enabling the new cohort and adult the population to survive throughout the austral summer.

\section{Latitudinal distribution of recruits}

The marked differences in Scytothalia dorycarpa recruit densities between southern and northern locations were consistent with the thermal sensitivities of early post-settlement germlings observed in the present study. Field studies of the latitudinal distribution and abundance of recruits found significantly lower $S$. dorycarpa recruit densities in northern reefs at which summer temperatures consistently exceed $23^{\circ} \mathrm{C}$ and sub $-20^{\circ} \mathrm{C}$ conditions last for $\sim 5$ mo compared to much higher recruit densities in southern reefs where average summer maximum temperatures peak at $\sim 22^{\circ} \mathrm{C}$, and sub- $20^{\circ} \mathrm{C}$ conditions persist for 6 to $7 \mathrm{mo}$. Post-settlement processes and recruitment are tightly coupled and often confine the abundance of fucoid species (Serrao et al. 1996, Johnson \& Brawley 1998, Berndt et al. 2002, Schiel \& Foster 2006). Low densities of $S$. dorycarpa recruits in northern locations might therefore be a direct reflection of the sensitivity of early post-settlement stages and the shorter window of time available for recruits to establish before warm, lethal summer temperatures commence.

Smale \& Wernberg (2013) found that conditions during the 2011 marine heat wave in south-western Australia exceeded the lethal limit for Scytothalia dorycarpa and were likely to have had detrimental physiological effects on adult stands. It is therefore possible that temperatures in northern locations may have temporarily exceeded the absolute limits for $S$. dorycarpa's persistence and led to recruit mortality and/or reproductive and recruitment failure in the subsequent 2011 winter. For seaweeds that hold reproductive structures throughout the entire year, such as $S$. dorycarpa, extreme temperatures during summer months may stress adult stands and potentially impact subsequent winter reproduction.

\section{Reproductive seasonality}

The timing of reproduction in Scytothalia dorycarpa to coincide with the coolest winter months was consistent with the optimal and lethal temperatures observed in the culturing experiment. Winter temperatures range from an average of 17 to $19^{\circ} \mathrm{C}$ across the geographical range observed in the present study, consistent with the 15 to $18^{\circ} \mathrm{C}$ temperatures found to optimise settlement and survivorship in culture. In $S$. dorycarpa, although reproductive structures (receptacles) are present throughout the entire year (Naylor 1949), the present study found gametogenesis (the development of gametes) to be seasonally constrained to winter months. This seasonal pattern contrasts with co-existing canopy formers that concentrate their reproductive outputs during the summer months, when the water temperature ranges from 20 to $23^{\circ} \mathrm{C}$. For example, local Ecklonia radiata populations reproduce from mid-summer to the end of autumn (Mohring et al. 2013), and local Sargassum spp. recruitment peaks in February (Kendrick \& Walker 1994). At the warm margin of a species range, reproduction during summer may expose sensitive early life history stages to stressful temperature and light conditions. In contrast, germlings such as $S$. dorycarpa, which settle in cooler months, may experience a more benign thermal environment. However, the challenge for $S$. dorycarpa is that on the west coast of Australia, sea temperatures are close to the early life stage lethal limit; therefore, slight increases in temperature may constrain reproduction by restricting the species' 'reproductive window'. Seasonally, $S$. dorycarpa has no room to move to escape warming conditions, so the only option for the species is to shift its geographical distribution poleward.

\section{CONCLUSIONS}

Our findings highlight the vulnerability of a key foundation species, Scytothalia dorycarpa, to changing ocean temperatures. Temperature-controlled culture experiments combined with seasonal and latitudinal observations indicated that the pre- and early post-settlement stages of the $S$. dorycarpa life cycle are sensitive to waters warmer than $20^{\circ} \mathrm{C}$. Whilst the acute temperature sensitivity of $S$. dorycarpa implies that it holds significant value as a bio-indicator of 
changes due to localised seawater warming, its longterm survival and recovery prospects around its current northern (warm) range limit are at risk under continued warming. Given the poleward flow of the Leeuwin current and negatively buoyant non-motile eggs of $S$. dorycarpa, natural recovery of northern populations is unlikely or will be extremely slow at best. Further studies of the ecology and population biology of $S$. dorycarpa will help to improve our understanding of the survival of this foundation species and the potential for its targeted rehabilitation in affected marginal populations.

Acknowledgements. The present study was supported by a grant from the Adaptation Research Network for Marine Biodiversity and Resources (NCCARF). S.A. was further supported by the Ray Hart Memorial Scholarship. Additional funding was provided by the Australian Research Council through grants to T.W.

\section{LITERATURE CITED}

Anderson MJ (2001) A new method for non-parametric multivariate analysis of variance. Austral Ecol 26:32-46

Berndt M, Callow JA, Brawley SH (2002) Gamete concentrations and timing and success of fertilization in a rocky shore seaweed. Mar Ecol Prog Ser 226:273-285

Bolton JJ, Lüning K (1982) Optimal growth and maximal survival temperatures of Atlantic Laminaria species (Phaeophyta) in culture. Mar Biol 66:89-94

Brawley SH, Johnson LE (1991) Survival of fucoid embryos in the intertidal zone depends upon developmental stage and microhabitat. J Phycol 27:179-186

Breeman A (1988) Relative importance of temperature and other factors in determining geographic boundaries of seaweeds: experimental and phenological evidence. Helgol Mar Res 42:199-241

Chu SH, Zhang QS, Liu SK, Tang YZ, Zhang SB, Lu ZC, Yu YQ (2012) Tolerance of Sargassum thunbergia germlings to thermal, osmotic and desiccation stress. Aquat Bot 96: $1-6$

Dayton PK (1972) Toward an understanding of community resilience and the potential effects of enrichments to the benthos at McMurdo Sound, Antarctica. In: Proceedings of the Colloquium on Conservation Problems. Allen Press, Lawrence, KS, p 81-96

> Depczynski M, Gilmour JP, Ridgway T, Barnes H and others (2012) Bleaching, coral mortality and subsequent survivorship on a West Australian fringing reef. Coral Reefs 32:233-238

> Deysher L, Norton TA (1981) Dispersal and colonization in Sargassum muticum (Yendo) Fensholt. J Exp Mar Biol Ecol 56:179-195

Edwards M, Hernández-Carmona G (2005) Delayed recovery of giant kelp near its southern range limit in the North Pacific following El Niño. Mar Biol 147:273-279

Feng M, McPhaden MJ, Xie SP, Hafner J (2013) La Niña forces unprecedented Leeuwin Current warming in 2011. Sci Rep 3:1277

Hiroko H, Noboru M, Yuzuru M, Mikio N, Goro Y, Toshi- nobu T (2005) The optimal and maximum critical temperatures of nine species of the Sargassaceae in the coastal waters of Yamaguchi Prefecture. Jap J Phycol 53:7-13

Huismann JM (2000) Marine plants of Australia. University of Western Australia Press, Perth

Irving AD, Connell SD, Gillanders BM (2004) Local complexity in patterns of canopy-benthos associations produces regional patterns across temperate Australasia. Mar Biol 144:361-368

> Johnson LE, Brawley SH (1998) Dispersal and recruitment of a canopy-forming intertidal alga: the relative roles of propagule availability and post-settlement processes. Oecologia 117:517-526

Kendrick GA, Walker DI (1994) Role of recruitment in structuring beds of Sargassum spp. (Phaeophyta) at Rottnest Island, Western Australia. J Phycol 30:200-208

> Kordas RL, Harley CDG, O'Connor MI (2011) Community ecology in a warming world: the influence of temperature on interspecific interactions in marine systems. J Exp Mar Biol Ecol 400:218-226

Ling SD (2008) Range expansion of a habitat-modifying species leads to loss of taxonomic diversity: a new and impoverished reef state. Oecologia 156:883-894

Lotze HK, Worm B, Sommer U (2001) Strong bottom-up and top-down control of early life stages of macroalgae. Limnol Oceanogr 46:749-757

> Lourey M, Dunn J, Waring J (2006) A mixed-layer nutrient climatology of Leeuwin Current and Western Australian shelf waters: seasonal nutrient dynamics and biomass. J Mar Syst 59:25-51

Lüning K (1984) Temperature tolerance and biogeography of seaweeds: the marine algal flora of Helgoland (North Sea) as an example. Helgol Meeresunters 38:305-317

Lüning K, Yarish C, Kirkman H (1990) Seaweeds: their environment, biogeography, and ecophysiology. John Wiley, New York, NY

McLachlan J, Chen LCM, Edelstein T (1971) The culture of four species of Fucus under laboratory conditions. Can J Bot 49:1463-1469

Mohring M, Wernberg T, Kendrick G, Rule M (2013) Reproductive synchrony in a habitat-forming kelp and its relationship with environmental conditions. Mar Biol 160: 119-126

Naylor M (1949) Some observations on the receptacles of Scytothalia dorycarpa, with special reference to the extrusion of the oogonia. Ann Bot (Lond) 13:135-149

Niemeck RA (1978) Physiological studies of intertidal algae. Bot Mar 21:221-228

Norton TA (1977) The growth and development of Sargassum muticum (Yendo) Fensholt. J Exp Mar Biol Ecol 26: 41-53

Pearce AF (1991) Eastern boundary currents of the southern hemisphere. J R Soc West Aust 74:34-45

Pearce AF, Feng M (2013) The rise and fall of the 'marine heat wave' off Western Australia during the summer of 2010/2011. J Mar Syst 111-112:139-156

Pearce A, Lenanton R, Jackson G, Moore J, Feng M, Gaughan D (2011) The 'marine heat wave' off Western Australia during the summer of 2010/11. Fisheries Res Rep No. 222, Western Australia Department of Fisheries, Perth

Phillips JA (2001) Marine macroalgal biodiversity hotspots: Why is there high species richness and endemism in southern Australian marine benthic flora? Biodivers Conserv 10:1555-1557 
Pollock EG (1970) Fertilization in Fucus. Planta 92:85-99

R Development Core Team (2012) R: a language and environment for statistical computing. R Foundation for Statistical Computing, Vienna, available at www.R-project. org

Root TL, Price JT, Hall KR, Schneider SH, Rosenzweig C, Pounds JA (2003) Fingerprints of global warming on wild animals and plants. Nature 421:57-60

Schiel DR, Foster MS (2006) The population biology of large brown seaweeds: ecological consequences of multiphase life histories in dynamic coastal environments. Annu Rev Ecol Evol Syst 37:343-372

Serrao EA, Pearson G, Kautsky L, Brawley SH (1996) Successful external fertilization in turbulent environments. Proc Natl Acad Sci USA 93:5286-5290

Setchell WA (1915) The law of temperature connected with the distribution of the marine algae. Ann Mo Bot Gard 2: 287-305

Smale DA, Wernberg T (2009) Satellite-derived SST data as a proxy for water temperature in nearshore benthic ecology. Mar Ecol Prog Ser 387:27-37

Smale DA, Wernberg T (2012) Ecological observations associated with an anomalous warming event at the Houtman Abrolhos Islands, Western Australia. Coral Reefs 31: 441

Smale DA, Wernberg T (2013) Extreme climatic event drives range contraction of a habitat-forming species. Proc $\mathrm{R}$ Soc Lond B Biol Sci 280:20122829

Smale DA, Kendrick GA, Wernberg T (2010) Assemblage turnover and taxonomic sufficiency of subtidal macroalgae at multiple spatial scales. J Exp Mar Biol Ecol 384: $76-86$

Stachowicz JJ (2001) Mutualism, facilitation, and the structure of ecological communities. Bioscience 51:235-246

Steen H, Scrosati R (2003) Intraspecific competition in Fucus serratus and F. evanescens (Phaeophyceae: Fucales)

Editorial responsibility: Morten Pedersen, Roskilde, Denmark germlings: effects of settlement density, nutrient concentration, and temperature. Mar Biol 144:61-70

> Thomsen MS, Wernberg T, Altieri A, Tuya F and others (2010) Habitat cascades: the conceptual context and global relevance of facilitation cascades via habitat formation and modification. Integr Comp Biol 50:158-175

> Tuya F, Cacabelos E, Duarte P, Jacinto D and others (2012) Patterns of landscape and assemblage structure along a latitudinal gradient in ocean climate. Mar Ecol Prog Ser 466:9-19

Van Den Hoek C (1982) The distribution of benthic marine algae in relation to the temperature regulation of their life histories. Biol J Linn Soc 18:81-144

> Vanderklift MA, Lavery PS, Waddington KI (2009) Intensity of herbivory on kelp by fish and sea urchins differs between inshore and offshore reefs. Mar Ecol Prog Ser 376:203-211

Walther GR, Post E, Convey P, Menzel A and others (2002) Ecological responses to recent climate change. Nature 416:389-395

Wernberg T, Thomsen MS, Tuya F, Kendrick GA, Staehr PA, Toohey BD (2010) Decreasing resilience of kelp beds along a latitudinal temperature gradient: potential implications for a warmer future. Ecol Lett 13:685-694

> Wernberg T, Russell B, Thomsen M, Gurgel F, Bradshaw C, Poloczanska E, Connell S (2011a) Seaweed communities in retreat from ocean warming. Curr Biol 21:1828-1832

> Wernberg T, Thomsen M, Tuya F, Kendrick G (2011b) Biogenic habitat structure of seaweeds change along a latitudinal gradient in ocean temperature. J Exp Mar Biol Ecol 400:264-271

Wernberg T, Smale DA, Tuya F, Thomsen MS and others (2013) An extreme climatic event alters marine ecosystem structure in a global biodiversity hotspot. Nature Clim Chang 3:78-82

Submitted: March 25, 2013; Accepted: September 20, 2013 Proofs received from author(s): December 3, 2013 